\title{
Reducing the iron burden and improving survival in transfusion-dependent thalassemia patients: current perspectives [Corrigendum]
}

Bayanzay K, Alzoebie L. J Blood Med. 2016;7:159—169.

On page 159, Keywords section, the keyword "deferiserox"

should have read "deferasirox".

The Journal of Blood Medicine is an international, peer-reviewed, open access, online journal publishing laboratory, experimental and clinical aspects of all aspect pertaining to blood based medicine including but not limited to: Transfusion Medicine; Blood collection, Donor issues, Transmittable diseases, and Blood banking logistics; Immunohematology; Artificial and alternative blood based therapeutics; Hematology; Biotechnology/nanotechnology of blood related medicine; Legal aspects of blood medicine; Historical perspectives. The manuscript management system is completely online and includes a very quick and fair peer-review system. Visit http://www.dovepress.com/ testimonials.php to read real quotes from published authors. 